\title{
Pengaruh Persepsi Konsumen terhadap Kualitas Layanan dan Minat Beli di Kota Langsa (Ritel Tradisional vs Modern)
}

\author{
Tengku Putri Lindung Bulan \\ Fakutas Ekonomi Universitas Samudra \\ e-mail:tengkuputri@unsam.ac.id \\ Riny Chandra \\ Fakutas Ekonomi Universitas Samudra \\ e-mail: rini.chandra@unsam.ac.id \\ Suri Amilia \\ Fakutas Ekonomi Universitas Samudra \\ e-mail:suri.amilia@unsam.ac.id
}

\begin{abstract}
Abstrak
Penelitian ini bertujuan untuk mengetahui: (1) pengaruh persepsi konsumen secara langsung terhadap kualitas layanan; (2) pengaruh persepsi konsumen secara langsung terhadap minat beli; (3) pengaruh kualitas layanan secara langsung terhadap minat beli; dan, (4) untuk mengetahui pengaruh persepsi konsumen secara tidak langsung terhadap minat beli melalui kualitas layanan, pada ritel tradisional dan modern di Kota Langsa. Jumlah sampel sebanyak 399 orang ditentukan melalui rumus Slovin, sementara pemilihan responden menggunakan teknik proportionate stratified random sampling. Metode analisis data menggunakan path analysis. Hasil penelitian membuktikan persepsi konsumen secara langsung berpengaruh signifikan terhadap kualitas layanan; persepsi konsumen secara langsung berpengaruh signifikan terhadap minat beli; kualitas layanan secara langsung berpengaruh signifikan terhadap minat beli; dan, persepsi konsumen secara tidak langsung berpengaruh tidak signifikan terhadap minat beli melalui kualitas layanan. Nilai koefisien determinasi bahwa 86,2\% informasi yang terkandung dalam data dapat dijelaskan oleh model, namun masih terdapat, sedangkan sisanya dijelaskan oleh error dan variabel lainnya di luar model penelitian.
\end{abstract}

Kata kunci: Persepsi konsumen, kualitas layanan, minat beli.

\section{PENDAHULUAN}

Berkembang dan bertambahnya jasa ritel di Indonesia khususnya Kota Langsa dari tahun ke tahun semakin meningkat tajam. Kondisi ini terlihat jelas dengan bertambah banyaknya jumlah ritel modern di Kota Langsa, sehingga berdampak pada keberadaan ritel tradisional, baik dari jumlah ritelnya ataupun konsumennya. Ritel Indonesia secara agregat dibagi menjadi dua, yaitu ritel modern dan ritel tradisional, pembagian ini dibuat oleh AC Nielsen Indonesia pada riset yang berjudul Shopper Trend 2003 (Amir, 2004).
Ritel modern yaitu ritel yang dikelola secara modern, lokasinya luas dan pola lokasinya terpusat pada satu gedung. Ritel ini menggunakan modal yang besar untuk mendirikan nya, gedungnya megah, ruangannya bersih, nyaman, display danlay out tertata dengan rapi. Keamanan terjamin karena sudah menggunakan teknologi yang canggih. Selain itu, perbedaan yang langsung bisa dirasakan oleh konsumen adalah konsumen dalam berbelanja mengambil sendiri sehingga sering disebut dengan self service (Sulistiyo, 2004). 
Pesatnya pembangunan ritel modern dirasakan oleh banyak pihak. Kehadiran pasar modern, seperti supermarket dan hypermarket dianggap oleh berbagai kalangan telah menyudutkan keberadaan pasar tradisional. Di Indonesia terdapat 13.450 pasar tradisional dengan sekitar 12,6 juta pedagang kecil (Kompas, 2006 dalam SMERU).

Munculnya pasar modern di Indonesia punya potensi besar untuk menggeser keberadaan pasar tradisional. Hal ini bermula dari Keppres No 96/2000 tentang usaha tertutup dan terbuka bagi penanaman modal asing (PMA) yang memasukkan ritel terbuka bagi asing, dan ritel asing-pun menguasai berbagai kota. Pasar tradisional pada tahun 2002-2008 turun 11,7\%. Sepuluh tahun terakhir, pedagang pasar tradisional turun $40 \%$. Hal ini menurut pengurus Asosiasi Pedagang Pasar Seluruh Indonesia (APSI) adalah akibat desakan Hipermarket dan pedagang tak mampu mempertahankan kios terenovasi karena tidak terjangkau biaya tebusnya (Sucipto, 2009).

Seiring perkembangan ritel saat ini, konsumen bukan hanya bertindak sebagai objek dalam penilaian terhadap kualitas pelayanan, melainkan telah menjadi salah satu subjek penentu dalam menilai kualitas pelayanan. Hal ini menuntut ritel sebagai pemasar memperhatikan dan memfokuskan setiap dimensi yang menjadiindikator utama penentu kualitas pelayanan yang memberikan kepuasan bagi pelanggan. Menurut Brady dan Cronin dalam Remiasa dan Lukman (2007), persepsi pelanggan terhadap kualitas layanan ini terdiri dari tiga kualitas, yaitu kualitas interaksi, kualitas lingkungan fisik, dan kualitas hasil. Ketiga kualitas ini membentuk keseluruhan persepsi pelanggan terhadap masing-masing kualitas layanan.

Persepsi konsumen terhadap kualitas pelayanan yang diberikan perlu dinilai berdasarkan sekumpulan kriteria yang berbeda karena mengingat kepentingan dan keterlibatan konsumen berbeda-beda. Dalam konsep perilaku konsumen, persepsi terhadap kualitas dari seorang konsumen adalah hal yang sangat penting, produsen berlombalomba dengan berbagai cara untuk dapat menghasilkan suatu produk atau jasa yang bagus menurut konsumen (Parji, 1991). Konsumen cenderung menilai kualitas suatu layanan yang diberikan berdasarkan faktorfaktor yang mereka asosiasikan dengan layanan yang dirasakannya. Faktor tersebut dapat bersifat internal dan faktor eksternal. Realitanya kualitas layanan harus melibatkan dua unsur, yaitu penyedia jasa dan konsumen yang memiliki perspektif dalam memberikan pendapat terhadap suatu barang (Goestch \& David dalam Tjiptono \& Diana, 2000). Persepsi konsumen tentang kualitas disinyalir merupakan salah satu faktor pembentuk minat membeli.

Fenomena di atas juga dirasakan di Kota Langsa, dimana luas wilayah administratif sebesar 262,41 $\mathrm{Km}^{2}$ dengan mayoritas penduduknya adalah pendatang juga mengalami kondisi yang kurang lebih sama persis. Pertumbuhan dan perkembangan ritel modern terlihat jelas dari jumlah supermarket, minimarket, grosir ataupun swalayan yang mengadopsi konsep ritel modern berada di hampir setiap sudut Kota Langsa. Hal ini menunjukkan dengan jelas dunia ritel saat ini didominasi oleh pasar modern. Namun demikian ritel tradisional di Kota Langsa tetap dapat mempertahankan eksistensinya di kalangan pelanggannya yang masih mempunyai minat beli walaupun banyak ritel modern yang baru atau yang lama sehingga ritel tradisional masih memiliki pelanggan yang setia juga.

Temuan ini menarik untuk digali lebih jauh, berkenaan dengan terjadinya perubahan perilaku konsumen dalam berbelanja yang disebabkan perbedaan persepsi konsumen terhadap kualitas layanan yang akhirnya dapat mempengaruhi minat beli konsumen untuk berbelanja pada ritel tradisional dan ritel modern.

Berdasarkan fenomena yang terkandung dalam latar belakang dan pemikiran teoritis, maka tujuan dalam penelitian ini adalah untuk mengetahui pengaruh persepsi konsumen secara langsung terhadap kualitas layanan pada ritel tradisional dan modern di Kota Langsa. Lebih terperinci, tujuan penelitian ini dengan obyek pada ritel tradisional dan 
modern di Kota Langsa adalah untuk mengetahui: (1) pengaruh persepsi konsumen secara langsung terhadap minat beli; (2) pengaruh kualitas layanan secara langsung terhadap minat beli; dan, (3) pengaruh persepsi konsumen secara tidak langsung terhadap minat beli melalui kualitas layanan.

\section{Ritel Tradisional dan Ritel Modern}

Dalam Perpres No 112 Tahun 2007 tentang Penataan dan Pembinaan Pasar Tradisional, Pusat Perbelanjaan dan Toko Modern, memberikan batasan mengenai ritel tradisional dan ritel modern dalam pasal 1 sebagai berikut

1. Pasar Tradisional, adalah pasar yang dibangun dan dikelola oleh Pemerintah, Pemerintah Daerah, Swasta, Badan Usaha Milik Negara dan Badan Usaha Milik Daerah, termasuk kerjasama dengan swasta pada tempat usaha berupa toko, kios, los dan tenda yang dimiliki/dikelola oleh pedagang kecil, menengah, swadaya masyarakat atau koperasi dengan usaha skala kecil, modal kecil dan dengan proses jual beli barang dagangan melalui tawar menawar.

2. Toko Modern, adalah toko dengan sistem pelayanan mandiri, menjual berbagai jenis barang secara eceran yang berbentuk Minimarket, Supermarket, Department Store, Hypermarket ataupun grosir yang berbentuk perkulakan. Batasan toko modern ini dipertegas di pasal 3, dalam hal luas lantai penjualan: (a) Minimarket memiliki luas kurang dari $400 \mathrm{~m}^{2}$ empat ratus meter persegi); (b) Supermarket memiliki luas $400 \mathrm{~m}^{2}$ (empat ratus meter persegi) sampai dengan $5.000 \mathrm{~m}^{2}$ (lima ribu meter per segi); (c) Hypermarket memiliki luas diatas $5.000 \mathrm{~m}^{2}$ (lima ribu meter persegi); (d) Department Store memiliki luas di atas $400 \mathrm{~m}^{2}$ (empatratus meter persegi); dan, (e) Perkulakan memiliki luas diatas $5.000 \mathrm{~m}^{2}$ (lima ribu meter persegi). Batasan pasar tradisional diatas nampak kurang mewakili pengertian ritel tradisional secara utuh. Hal ini karena, berbeda dengan batasan toko modern yang terperinci mulai dari bentuk yang terkecil (minimarket) hingga yang terbesar (hypermarket), batasan pasar tradisional hanya menjelaskan adanya tempat yang luas (atau cukup luas) untuk melokalisasi toko, kios, dan petak-petak, sebagai tempat usaha milik para pedagang dan tempat masyarakat membeli barang-barang kebutuhan sehari-hari.

Oleh karena itu, bila menggunakan klasifikasi bentuk ritel dalam mengkaji persaingan ritel tradisional dan ritel modern, agar berimbang dengan batasan toko modern yangterperinci dalam berbagai ukuran, maka perlu ditambahkan jenis ritel ukuran-ukuran kecil dalam ritel tradisional seperti toko, kios, dan warung yang tidak berada dalam lokasi pasar. Persaingan antara ritel tradisional dan ritel modern terjadi antara jenis ritel dalam ukuran yang kurang lebih sama: minimarket dengan toko dan kios di sekitarnya; ataupun pasar tradisional dengan supermarket atau hypermarket.

\section{Perbedaan Karakteristik Ritel Tradisional dan Ritel Modern}

Badan usaha penjualan eceran sangat beraneka ragam dan bentuk-bentuk baru pun mulai terus bermunculan. Beberapa pengelompokkan telah ditemukan. Menurut Sujana (2005), tipe bisnis retail dapat diklasifikasikan berdasarkan kepemilikan bisnis, barang dagang, area penjualan. Tambunan dkk. (2004) membagi bisnis ritel menjadi 2 (dua) kategori, yaitu ritel tradisional dan ritel modern. Gambaran adanya perbedaan antara keduanya, ditunjukkan pada Tabel 1 .

\section{Persepsi Konsumen}

Menurut Schiffman dan Kanuk (2008), persepsi adalah sebagai proses yang dilakukan individu untuk memilih, mengatur, dan menafsirkan stimuli ke dalam gambar yang berarti dan masuk akal mengenai dunia. Faktor utama dari persepsi ini adalah imej (image) yang dapat membantu konsumen untuk memutuskan dimana akan berbelanja. Pembentuk dari imej adalah harga, kualitas, lingkungan fisik, keberagaman barang, pelayanan, dan lokasi. 
Tabel 1. Pembagian Retail Modern dan Tradisional

\begin{tabular}{|c|c|c|}
\hline Klasifikasi & Retail Modern & Retail Tradisional \\
\hline Lini Produk & $\begin{array}{l}\text { Toko Khusus } \\
\text { Toko Serba Ada } \\
\text { Toko Swalayan } \\
\text { Toko Convenience } \\
\text { Toko Super, Kombinasi, } \\
\text { dan Pasar Hyper } \\
\text { Toko Diskon } \\
\text { Pengecer Potomgan Harga } \\
\text { Ruang Penjual Katalog }\end{array}$ & $\begin{array}{l}\text { Mom \& Pop Store } \\
\text { Mini Market }\end{array}$ \\
\hline Kepemilikan & * Corporate Chain Store & Independent Store \\
\hline Penggunaan Fasilitas & $\begin{array}{l}\text { Alat-alat Pembayaran } \\
\text { modern (Computer, credit } \\
\text { card, autodebet) } \\
\text { AC, Eskalator/ Lift }\end{array}$ & $\begin{array}{l}\text { Alat Pembayaran } \\
\text { Tradisional(manual/ } \\
\text { calculator, cash) } \\
\text { Tangga, tanpa AC }\end{array}$ \\
\hline Promosi & * Ada & * Tidak Ada \\
\hline Keuangan & $\begin{array}{l}\text { Tercatat dan Dapat } \\
\text { dipublikasikan }\end{array}$ & $\begin{array}{l}\text { Belum tentu tercatat dan } \\
\text { tidak dipublikasikan }\end{array}$ \\
\hline Tenaga Kerja & * Banyak & * Sedikit, biasanya keluarga \\
\hline Fleksibilitas Operasi & * Tidak Fleksibel & Fleksibel \\
\hline
\end{tabular}

Sumber: Tambunan dkk., tahun 2004

\section{Persepsi Konsumen}

Menurut Schiffman dan Kanuk (2008), persepsi adalah sebagai proses yang dilakukan individu untuk memilih, mengatur, dan menafsirkan stimuli ke dalam gambar yang berarti dan masuk akal mengenai dunia. Faktor utama dari persepsi ini adalah imej (image) yang dapat membantu konsumen untuk memutuskan dimana akan berbelanja. Pembentuk dari imej adalah harga, kualitas, lingkungan fisik, keberagaman barang, pelayanan dan lokasi.

Indikator mengenai persepsi dikutip dari penelitian Siringoringo dkk. (2009) yang menyatakan bahwa variabel persepsi diukur menggunakan tiga indikator: (1) persepsi akan harga barang yang dijual dalam toko ritel; (2) persepsi akan mutu barang yang dijual; dan, (3) persepsi akan kelengkapan barang yang tersedia di toko ritel.

\section{Kualitas Layanan}

Menurut Tjiptono (2004), kualitas yaitu suatu kondisi dinamis yang berhubungan dangan produk, jasa, proses, manusia dan lingkungan yang memenuhi atau melebihi harapan. Selanjutnya menurut Lewis dan Booms dalam Tjiptono dan Chandra (2005), kualitas pelayanan jasa adalah ukuran seberapa bagus tingkat layanan yang diberikan bisa sesuai ekspektasi pelanggan.

Menurut Dabholkar et al. (1996), dimensi kualitas pelayanan jasa ritel meliputi lima faktor utama, yaitu:

1. Aspek Fisik (physical aspects), meliputi penampilan fasilitas fisik dan kenyamanan yang ditawarkan kepada pelanggan berkaitan dengan layout fasilitas fisik, misalnya: memudahkan pelanggan untuk bergerak didalam toko dan mencari barang yang dibutuhkan, fasilitas fisik

2. Reliabilitas (reliability), yang prinsipnya sama dengan dimensi reliabilitas pada model SERVQUAL. Hanya saja, di sini reliabilitas dipilah ke dalam dua subdimensi, yaitu memenuhi janji dan memberikan layanan dengan tepat.

3. Interaksi personal (personal interaction), mengacu pada kemampuan karyawan jasa dalam menumbuhkan kepercayaan pihak 
pelanggan dan sikap sopan atau suka membantu. Pada prinsipnya, dimensi ini berkaitan dengan bagaimana cara para karyawan memperlakukan pelanggan.

4. Pemecahan masalah (problem solving), berhubungan dengan penanganan retur, penukaran dan komplain.

5. Kebijakan (policy), mencakup aspek-aspek kualitas jasa yang secara langsung dipengaruhi kebijakan toko, seperti jam operasi, fasilitas parkir, dan pemakaian kartu kredit.

\section{Minat Beli}

Hasan (2013) menyatakan bahwa minat beli merupakan kecenderungan konsumen untuk membeli suatu merek atau mengambil tindakan guna terkait dengan pembelian yang diukur dengan probabilitas kemungkinan konsumen melakukan pembelian.

Menurut Crow dan Crow (dalam Hurlock, 1994), ada tiga faktor yang menjadi timbulnya minat, yaitu:

1. Dorongan dari dalam diri individu, misal dorongan untuk makan. Dorongan untuk makan akan membangkitkan minat untuk bekerja atau mencari penghasilan, minat terhadap produksi makanan dan lain-lain. Dorongan ingin tahu atau rasa ingin tahu akan membangkitkan minat untuk membaca, belajar, menuntut ilmu, melakukan penelitian dan lain-lain.

2. Motif sosial, dapat menjadi faktor yang membangkitkan minat untuk melakukan suatu aktivitas tertentu. Misalnya minat terhadap pakaian timbul karena ingin mendapatkan persetujuan atau penerimaan dan perhatian orang lain. Minat untuk belajar atau menuntut ilmu pengetahuan timbul karena ingin mendapat penghargaan dari masyarakat, karena biasanya yang memiliki ilmu pengetahuan cukup luas (orang pandai) mendapat kedudukan yang tinggi dan terpandang dalam masyarakat.

3. Faktor emosional, yaitu minat mempunyai hubungan yang erat dengan emosi. Bila seseorang mendapatkan kesuksesan pada aktivitas akan menimbulkan perasaan senang, dan hal tersebut akan memperkuat minat atas aktivitas tersebut; sebaliknya, suatu kegagalan akan menghilangkan minat terhadap hal tersebut.

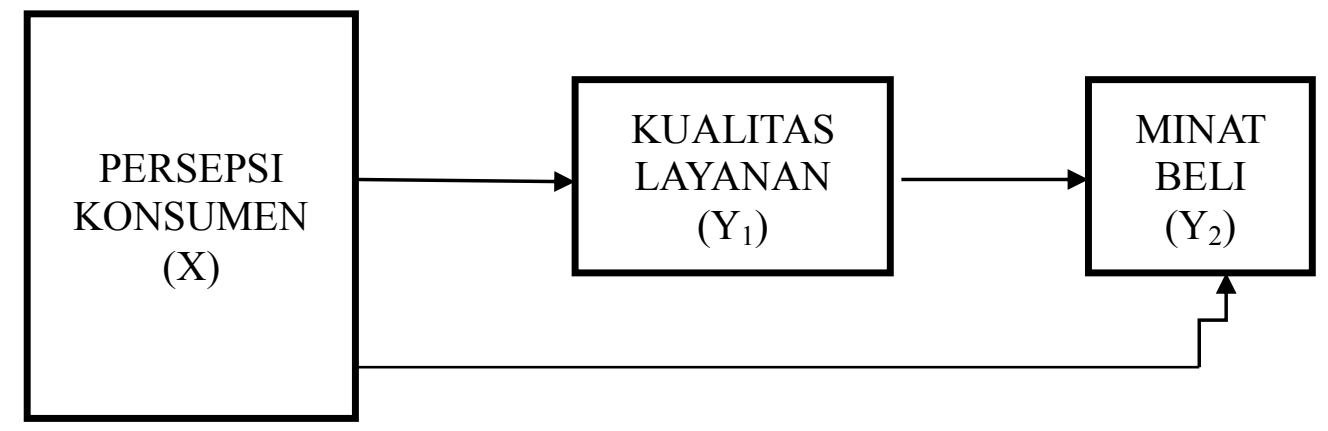

Sumber: Diolah peneliti, tahun 2018.

\section{Gambar 1. Kerangka Teori}

\section{Hipotesis}

Berdasarkan kerangka teori pada Gambar 1 maka terdapat empat hipotesis yang diajukan dalam penelitian ini: (1) Persepsi konsumen secara langsung berpengaruh signifikan terhadap kualitas layanan pada ritel tradisional dan modern di Kota Langsa; (2) Persepsi konsumen secara langsung berpengaruh signifikan terhadap minat beli pada ritel tradisional dan modern di Kota Langsa; (3) Kualitas layanan secara langsung berpengaruh signifikan terhadap minat beli pada ritel tradisional dan modern di Kota Langsa; dan, (4) Persepsi konsumen secara tidak langsung berpengaruh signifikan terhadap minat beli pada ritel tradisional dan modern di Kota Langsa melalui kualitas layanan. 


\section{METODE PENELITIAN}

Penelitian dilakukan pada ibu-ibu atau pemudi yang pernah berbelanja di ritel tradisional dan ritel modern di Kota Langsa. Jenis penelitian ini deskriptif kuantitatif yang bersumber dari data primer dan data sekunder.

Populasi dalam penelitian ini adalah ibu-ibu atau pemudi yang pernah berbelanja di pasar tradisional atau juga pernah berbelanja di pasar modern di Kota Langsa yang bertempat tinggal di Kota Langsa selama kurun waktu penelitian. Populasi dalam penelitian ini merupakan jumlah penduduk Kota Langsa pada tahun 2016 yang memiliki jumlah sebesar 168.820 orang (www.langsakota.bps.go.id, 2017).

Metode pengambilan sampel dalam penelitian ini menggunakan Rumus Slovin (Riduwan, 2005) sebagai berikut:

$$
\mathrm{n}=\mathrm{N} / \mathrm{N}(\mathrm{d})^{2}+1
$$

dimana $n$ adalah sampel; $N$ adalah populasi; $d$ adalah nilai presisi $95 \%$ (sig. $=0,05)$.

Dikarenakan jumlah populasinya adalah 168.820 orang, dan tingkat kesalahan yang dikehendaki adalah 5\%, maka jumlah sampel yang digunakan adalah 399,05 atau dibulatkan menjadi 399 orang.

Selanjutnya, sampel sebesar 399 responden itu disebar atas lima kecamatan Kota Langsa. Jumlah sampel yang diambil berdasarkan masing-masing kecamatan itu ditentukan kembali menggunakan teknik Proportionate Stratified Random Sampling, yaitu sebagai berikut:

1. Langsa Timur $=15.215 / 168.820 \times 399=$ 35,96 atau dibulatkan 36 orang.

2. Langsa Lama $=30.116 / 168.820 \times 399=$ 71,17 atau dibulatkan 71 orang.

3. Langsa Barat $=34.849 / 168.820 \times 399=$ 82,36 atau dibulatkan 82 orang.

4. Langsa Baro $=47.570 / 168.820 \times 399=$ 112,42 atau dibulatkan 113 orang.

5. Langsa Kota $=41.070 / 168.820 \times 399=$ 97,06 atau dibulatkan 97 orang.

Dengan demikian, keseluruhan sampel itu adalah $36+71+82+113+97=399$ responden. Rangkuman perhitungan ditunjukkan pada Tabel 2.

Tabel 2. Sebaran Proporsi Responden

\begin{tabular}{ccccc}
\hline No. & Kecamatan & Jml Penduduk (org) & Perhitungan Proporsi & Jml Responden (org) \\
\hline 1 & Langsa Timur & 15.215 & $15.215 / 168.820 \times 399$ & $35,96 \approx 36$ \\
2 & Langsa Lama & 30.116 & $30.116 / 168.820 \times 399$ & $35,96 \approx 36$ \\
3 & Langsa Barat & 34.849 & $34.849 / 168.820 \times 399$ & $35,96 \approx 36$ \\
4 & Langsa Baro & 47.570 & $47.570 / 168.820 \times 399$ & $35,96 \approx 36$ \\
5 & Langsa Kota & 41.070 & $41.070 / 168.820 \times 399$ & $35,96 \approx 36$ \\
\hline & Total Jumlah & 168.820 & & 399 \\
\hline
\end{tabular}

Sumber: Data sekunder (diolah), tahun 2018

Teknik pengumpulan data dilakukan dengan membagikan kuesioner dengan skala Likert. Kuesioner diberikan kepada ibu-ibu atau pemudi yang pernah berbelanja di pasar tradisional dan juga pernah berbelanja di pasar modern di Kota Langsa, untuk mengetahui tanggapan mereka mengenai minat beli yang dipengaruhi oleh persepsi konsumen dan kualitas layanan sebagai variabel Intervening.

Metode yang digunakan untuk analisis data adalah peralatan analisis jalur (Path Analysis) yang merupakan pengembangan langsung bentuk regresi linier berganda dengan tujuan untuk memberikan estimasi tingkat kepentingan (magnitude) dan signifikansi (significance) hubungan sebab akibat hipotetikal dalam seperangkat variabel (Sarwono, 2007). Model analisis jalur tersebut terdiri atas dua persamaan struktural dengan dua substruktural, yaitu $X$ sebagai variabel eksogen dan $Y_{1}$ dan $Y_{2}$ sebagai variabel endogen. Persamaan struktural tersebut adalah sebagai berikut:

$$
\begin{aligned}
& \mathrm{Y}_{1}=\mathrm{PY}_{1} \mathrm{X}+\mathrm{e}_{1} \quad \text { (substruktural 1) } \\
& \mathrm{Y}_{2}=\mathrm{PY}_{2} \mathrm{X}+\mathrm{PY}_{2} \mathrm{Y}_{1}+\mathrm{e}_{2} \quad \text { (substruktural 2) }
\end{aligned}
$$


dimana $\mathrm{Y}_{1}$ adalah kualitas Layanan; $\mathrm{Y}_{2}$ adalah Minat Beli; X adalah Persepsi Konsumen; P adalah Koefisien Regresi; dan, $\mathrm{e}_{1}, \mathrm{e}_{2}$ adalah Term of Error.

Pengujian hipotesis dalam penelitian ini dengan membandingkan besaran probabilitas signifikansi $(p)$ dengan taraf signifikansi $(\alpha)$ sebesar 0,05. Apabila perbandingan nilai probabilitas signifikansi (p) lebih kecil bila dibandingkan dengan nilai taraf signifikansi $(\alpha)$, maka hipotesis yang diajukan dapat diterima; sedangkan apabila nilai probabilitas signifikansi (p) lebih besar dari nilai taraf signifikansi $(\alpha)$, maka hipotesis ditolak. Kriteria keputusan bahwa $\mathrm{H}_{0}$ diterima jika nilai Sig (p-value $)>\alpha(0,05)$ yang berarti tidak signifikan; atau, $\mathrm{H}_{0}$ ditolak jika nilai $\mathrm{Sig}$ (p-value $)<\alpha(0,05)$ yang berarti signifikan.

Koefisien determinasi pada intinya mengukur seberapa jauh kemampuan model dalam menerangkan variasi variabel-variabel independen. Nilai koefisien determinasi yaitu antara nol dan satu. Nilai $\mathrm{R}^{2}$ yang kecil berarti kemampuan variabel-variabel independen dalam menjelaskan variasi variabel dependen amat terbatas. Nilai yang mendekati satu berarti variabel-variabel independen memberikan hampir semua informasi yang dibutuhkan untuk memprediksi variasi variabel dependen (Ghozali, 2012).

\section{HASIL ANALISIS}

\section{Model Analisis Jalur Subtruktur I}

Hasil pengolahan data dirangkum dalam Tabel 3. Berdasarkan tabel tersebut. maka persamaan analisis jalur untuk persamaan substruktur I dalam penelitian ini adalah:

$$
\mathrm{Y}_{1}=0,783 \mathrm{X}+\mathrm{e}_{1}
$$

Dari Tabel 3. terlihat bahwa nilai $R$ Square yang diperoleh sebesar 0,395 atau $39,5 \%$. Nilai tersebut menunjukkan bahwa kemampuan variabel persepsi konsumen dalam menjelaskan variasi yang terjadi pada kualitas layanan sebesar 39,5\%; sedangkan sisanya sebesar $60,5 \%$ dipengaruhi variabel lain yang tidak teliti di dalam model penelitian ini.

Tabel 3. Model Analisis Jalur Substruktur I

\begin{tabular}{cccc}
\hline Variabel & $\mathrm{B}$ & $\mathrm{t}$ & Sig. t \\
\hline Konstanta & 3,962 & 3,763 & 0,000 \\
Persepsi Konsumen & 0,783 & 16,106 & 0,000 \\
\hline R Square & 0,395 & & \\
\hline
\end{tabular}

Sumber: Data Primer (diolah), tahun 2018.

Tabel 4. Model Analisis Jalur Subtruktur II

\begin{tabular}{lccc}
\hline \multicolumn{1}{c}{ Variabel } & $\mathrm{B}$ & $\mathrm{t}$ & Sig. t \\
\hline Konstanta & 2,668 & 2,164 & 0,031 \\
Persepsi Konsumen & 0,458 & 6,312 & 0,000 \\
Kualitas Layanan & 0,423 & 7,255 & 0,000 \\
\hline \multicolumn{1}{c}{ R Square } & 0,385 & & \\
\hline
\end{tabular}

Sumber: Data Primer, diolah (2018)

\section{Model Analisis Jalur Substruktur II}

Berdasarkan Tabel 4, maka persamaan analisis jalur untuk persamaan substruktur II dalam penelitian ini adalah:

$$
\mathrm{Y}_{2}=0,458 \mathrm{X}+0,423 \mathrm{Y}_{1}+\mathrm{e}_{2}
$$

Dari Tabel 4 terlihat nilai $R$ Square yang diperoleh sebesar 0,385 atau $38,5 \%$. Hal ini menunjukkan kemampuan variabel persepsi konsumen dan kualitas layanan dalam menjelaskan variasi pada minat beli sebesar $38,5 \%$; sedangkan sisanya sebesar $61,5 \%$ dipengaruhi variabel lain yang tidak teliti. 


\section{Uji Model Struktural}

Untuk menghitung pengaruh langsung digunakan formula sebagai berikut.

- Pengaruh variabel persepsi konsumen (X) terhadap kualitas layanan $\left(\mathrm{Y}_{1}\right)$ :

$\mathrm{X}$ terhadap $\mathrm{Y}_{1}=0,783$

- Pengaruh variabel persepsi konsumen (X) terhadap minat beli $\left(\mathrm{Y}_{2}\right)$ :

$\mathrm{X}$ terhadap $\mathrm{Y}_{2}=0,458$

- Pengaruh variabel kualitas layanan $\left(\mathrm{Y}_{1}\right)$ terhadap minat beli $\left(\mathrm{Y}_{2}\right)$ :

$\mathrm{Y}_{1}$ terhadap $\mathrm{Y}_{2}=0,423$

Untuk menghitung besar pengaruh tidak langsung digunakan formula sebagai berikut:

- Pengaruh variabel persepsi konsumen (X) terhadap minat beli $\left(\mathrm{Y}_{2}\right)$ melalui kualitas layanan $\left(\mathrm{Y}_{1}\right)$ :

$\mathrm{X}$ melalui $\mathrm{Y}_{1}$ terhadap $\mathrm{Y}_{2}$

$=0,783 \times 0,423=0,331$
Untuk menghitung besar pengaruh total digunakan formula sebagai berikut:

- Total pengaruh variabel persepsi konsumen (X) terhadap variabel minat beli $\left(\mathrm{Y}_{2}\right)$ melalui kualitas layanan $\left(\mathrm{Y}_{1}\right)$ :

$\mathrm{X}$ melalui $\mathrm{Y}_{1}$ terhadap $\mathrm{Y}_{2}$

$=0,783+0,423=1,206$

Berdasarkan penjelasan tersebut dapat digambarkan diagram jalur pada Gambar 2, dimana:

- Substruktur I : $\mathrm{Y}_{1}=0,783 \mathrm{X}+\mathrm{e}_{1}$

- Substruktur II: $\mathrm{Y}_{2}=0,458 \mathrm{X}+0,423 \mathrm{Y}_{1}+\mathrm{e}_{2}$

Besarnya nilai error pada pengaruh dari masing-masing pengaruh variabel independen terhadap variabel dependen diperoleh melalui perhitungan sebagai berikut:

$$
\begin{aligned}
& \mathrm{Pe}_{1}=1-0,395=0,605 \\
& \mathrm{Pe}_{2}=1-0,385=0,615
\end{aligned}
$$

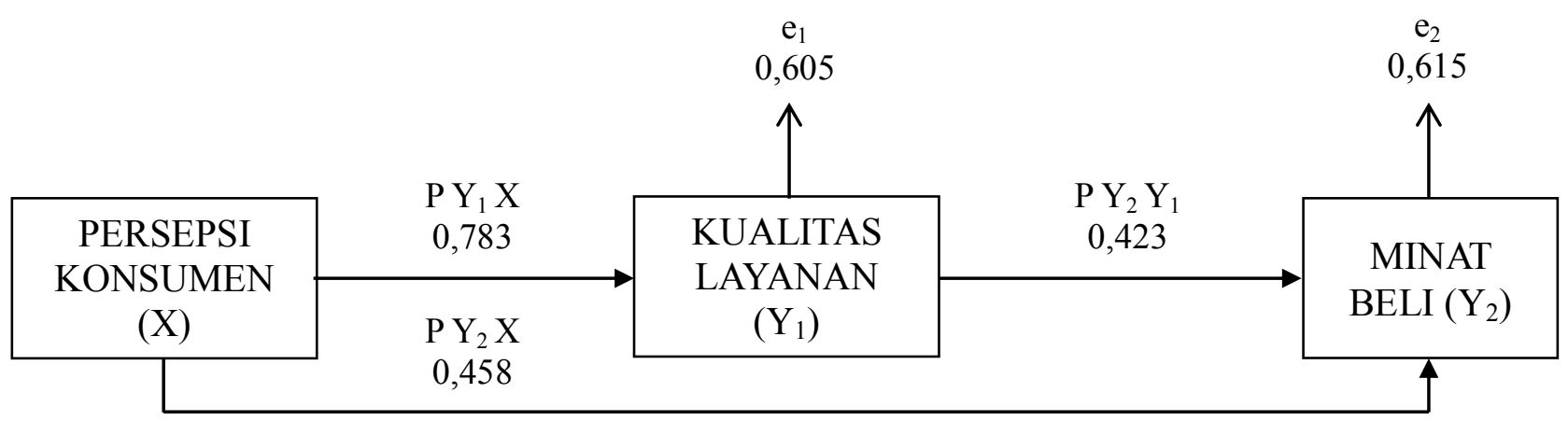

Sumber: Data primer (diolah), tahun 2018.

\section{Gambar 2. Hasil Diagram Jalur}

Dalam teori trimming, pengujian unsur validitas model riset diamati melalui perhitungan koefisien determinasi total sebagai berikut:

$$
\begin{aligned}
\mathrm{Rm}^{2} & =1-\left(0,605^{2}\right)\left(0,615^{2}\right) \\
& =1-(0,366)(0,378) \\
& =1-0,138 \\
& =0,862 \\
& =86,2 \%
\end{aligned}
$$

Nilai koefisien determinasi total diperoleh sebesar 0,862 menunjukkan bahwa $86,2 \%$ informasi yang terkandung dalam data dapat dijelaskan oleh model, sedangkan sisanya sebesar $13,8 \%$ dijelaskan oleh error dan variabel lainnya di luar model penelitian. Angka koefisien pada model ini relatif cukup besar sehingga layak dilakukan interpretasi lebih lanjut.

Pada analisis jalur (Gambar 2) memperlihatkan pengaruh langsung persepsi konsumen yang terdiri dari:

1. Persepsi konsumen berpengaruh langsung terhadap kualitas layanan sebesar 0,783

2. Persepsi konsumen berpengaruh langsung terhadap minat beli sebesar 0,458

3. Kualitas layanan berpengaruh langsung terhadap minat beli sebesar 0,423

Sedangkan pengaruh tidak langsung melalui kualitas layanan terhadap minat beli, yaitu untuk variabel persepsi konsumen berpengaruh secara tidak langsung terhadap minat beli melalui kualitas layanan sebesar 
0,338 . Selanjutnya, pengaruh total terhadap minat beli melalui kualitas layanan yaitu: total pengaruh persepsi konsumen terhadap minat beli melalui kualitas layanan sebesar 1,215.

\section{Pengujian Hipotesis}

Hipotesis pertama menyatakan bahwa persepsi konsumen secara langsung berpengaruh signifikan terhadap kualitas layanan pada ritel tradisional dan modern di Kota Langsa. Berdasarkan hasil pada Tabel 3, diperoleh bahwa nilai probabilitas ( $\mathrm{p}$-value) signifikansi untuk variabel persepsi konsumen sebesar $0,000<\alpha(0,05)$. Dari hasil yang diperoleh maka hipotesis pertama dapat dibuktikan atau diterima bahwa secara langsung persepsi konsumen berpengaruh signifikan terhadap kualitas layanan pada ritel tradisional dan modern di Kota Langsa.

Hipotesis kedua menyatakan bahwa persepsi konsumen secara langsung berpengaruh signifikan terhadap minat beli pada ritel tradisional dan modern di Kota Langsa. Berdasarkan hasil pada Tabel 4, diperoleh bahwa nilai probabilitas ( $\mathrm{p}$-value) signifikansi untuk variabel persepsi konsumen sebesar $0,000<\alpha(0,05)$. Dari hasil yang diperoleh maka hipotesis dapat dibuktikan atau diterima bahwa secara langsung variabel persepsi konsumen berpengaruh signifikan terhadap minat beli pada ritel tradisional dan modern di Kota Langsa.

Hipotesis ketiga menyatakan bahwa kualitas layanan secara langsung berpengaruh signifikan terhadap minat beli pada ritel tradisional dan modern di Kota Langsa. Berdasarkan hasil pada Tabel 4. menunjukkan bahwa nilai probabilitas ( $\mathrm{p}$-value) signifikansi untuk variabel kualitas layanan sebesar 0,000 $<\alpha(0,05)$. Dari hasil yang diperoleh maka hipotesis dapat dibuktikan atau diterima bahwa secara langsung variabel kualitas layanan berpengaruh signifikan terhadap minat beli pada ritel tradisional dan modern di Kota Langsa.

Hipotesis keempat menyatakan bahwa persepsi konsumen secara tidak langsung berpengaruh signifikan terhadap minat beli pada ritel tradisional dan modern di Kota Langsa melalui kualitas layanan. Berdasarkan hasil diketahui bahwa pengaruh langsung yang diberikan variabel persepsi konsumen terhadap minat beli sebesar 0,458 . Sedangkan pengaruh tidak langsung variabel persepsi konsumen terhadap minat beli melalui kualitas layanan adalah perkalian antara nilai $\mathrm{B}$ variabel persepsi konsumen atas variabel minat beli yaitu $\mathrm{X}$ melalui $\mathrm{Y}_{1}$ terhadap $\mathrm{Y}_{2}=$ $0,783 \times 0,423=0,331$. Selanjutnya pengaruh total yang diberikan variabel persepsi konsumen terhadap variabel minat beli adalah pengaruh langsung ditanbah dengan pengaruh tidak langsung yaitu $X$ melalui $\mathrm{Y}_{1}$ terhadap $\mathrm{Y}_{2}$ $=0,783+0,423=1,206$.

Dengan demikian dari hasil analisis diperoleh bahwa nilai pengaruh langsung sebesar 0,458 dan pengaruh tidak langsung sebesar 0,331 yang berarti bahwa nilai pengaruh tidak langsung lebih kecil dibandingkan dengan nilai pengaruh langsung. Hasil ini menunjukkan bahwa secara tidak langsung persepsi konsumen melalui kualitas layanan mempunyai pengaruh yang tidak signifikan terhadap minat beli pada ritel tradisional dan modern di Kota Langsa. Dengan demikian, hipotesis keempat ditolak atau tidak dapat dibuktikan.

\section{Pembahasan}

\section{a. Pengaruh Persepsi Konsumen secara Langsung terhadap Kualitas Layanan}

Hipotesis pertama yang menyatakan bahwa persepsi konsumen secara langsung berpengaruh signifikan terhadap kualitas layanan. Berdasarkan Tabel 3. diperoleh nilai probabilitas (p-value) signifikansi untuk variabel persepsi konsumen sebesar $0,000<\alpha$ $(0,05)$ maka hipotesis diterima. Artinya variabel persepsi konsumen secara langsung berpengaruh signifikan terhadap kualitas layanan pada ritel tradisional dan modern di Kota Langsa; dan persepsi konsumen berpengaruh secara langsung atas kualitas layanan yaitu sebesar 0,783 .

Hasil ini mengindikasikan bahwa semakin meningkatnya persepsi konsumen terhadap kualitas layanan terutama yang terlihat dari tiga indikator yang digunakan baik dari persepsi akan harga barang yang dijual dalam toko ritel, persepsi akan mutu 
barang yang dijual, maupun persepsi akan kelengkapan barang yang tersedia di toko ritel maka akan memberikan pengaruh secara langsung yang signifikan terhadap kualitas layanan pada ritel tradisional dan modern di Kota Langsa. Hasil penelitian ini sama dengan penelitian Siringoringo dkk. (2009) yang menyatakan pentingnya manajemen ritel memperhatikan pembentukan persepsi atas toko ritel jika ingin membentuk pengalaman berbelanja yang bagus dalam keputusan pembelian sehari-hari. Dengan demikian, kondisi ini dinilai akan berdampak pada meningkatnya kualitas pelayanan pada ritel tradisional dan modern di Kota Langsa.

\section{b. Pengaruh Persepsi Konsumen secara Langsung terhadap Minat Beli}

Hipotesis kedua menyatakan bahwa persepsi konsumen secara langsung berpengaruh signifikan terhadap minat beli. Berdasarkan Tabel 4 diperoleh nilai probabilitas (p-value) signifikansi untuk variabel persepsi konsumen sebesar $0,000<\alpha(0,05)$ maka hipotesis diterima. Artinya variabel persepsi konsumen secara langsung berpengaruh signifikan terhadap minat beli pada ritel tradisional dan modern di Kota Langsa; dan persepsi konsumen berpengaruh secara langsung terhadap minat beli yaitu 0,458.

Hasil ini mengindikasikan persepsi konsumen yang indikatornya terdiri dari persepsi akan harga barang yang dijual dalam toko ritel, persepsi akan mutu barang yang dijual, maupun persepsi akan kelengkapan barang yang tersedia di toko ritel memberikan pengaruh tidak langsung yang signifikan terhadap minat beli melalui kualitas layanan pada ritel tradisional dan modern di Kota Langsa. Hasil penelitian ini sama dengan penelitian Woodside dalam Setyawan dan Ihwan (2004) yang menyatakan pelanggan menilai sikap dari pemberi jasa sebagai ekspektasi awal mengenai kinerja toko, dan sikap ini mempengaruhi minat pembelian pada sebuah toko. Selain itu, penelitian yang dilakukan Taylor dan Baker (1994) menunjukkan variabel persepsi kualitas layanan dan kepuasan berpengaruh terhadap niat pembelian. Hal ini berarti jika persepsi konsumen terhadap harga barang, mutu barang dan kelengkapan barang di ritel semakin baik maka minat untuk melakukan pembelian akan semakin meningkat.

\section{c. Pengaruh Kualitas Layanan secara Langsung terhadap Minat Beli}

Hipotesis ketiga yang menyatakan bahwa kualitas layanan secara langsung berpengaruh signifikan terhadap minat beli. Berdasarkan Tabel 4 diperoleh nilai probabilitas (p-value) signifikansi untuk variabel persepsi konsumen sebesar $0,000<\alpha(0,05)$ maka hipotesis bisa dibuktikan atau diterima. Artinya, variabel kualitas layanan secara langsung berpengaruh signifikan terhadap minat beli pada ritel tradisional dan modern di Kota Langsa; dan, kualitas layanan berpengaruh secara langsung terhadap minat beli yaitu 0,423 .

Kualitas pelayanan adalah faktor pendukung penting yang tidak dapat dilepaskan fungsinya untuk meningkatkan minat pembelian produk atau jasa perusahaan (Utami, 2006). Setiap konsumen tentunya akan memperhatikan dan membandingkan kualitas pelayanan yang diberikan oleh karyawan ritel, dan ini merupakan salah satu alat ukur bagi konsumen tersebut yang nantinya akan tetap setia atau loyal terhadap ritel tersebut atau justru akan mencari tempat lain yang dirasa mempunyai kualitas pelayanan yang lebih baik.

Hasil penelitian ini serupa dengan penelitian Woodside dalam Setyawan dan Ihwan (2004) menyatakan bahwa pelanggan menilai sikap dari pemberi jasa sebagai ekspektasi awal mengenai kinerja toko dan sikap ini mempengaruhi minat pembelian pada sebuah toko. Dengan demikian dapat disimpulkan bahwa kualitas layanan yang indikatornya terdiri dari aspek fisik, reliabilitas, interaksi personal, pemecahan masalah dan kebijakan memberikan pengaruh secara langsung yang signifikan terhadap minat beli pada ritel tradisional dan modern di Kota Langsa. Hal ini berarti semakin baik kualitas layanan yang diberikan toko ritel maka akan dapat mempengaruhi minat pembelian pada toko ritel. 


\section{d. Pengaruh Persepsi Konsumen secara Tidak Langsung terhadap Minat Beli melalui Kualitas Layanan}

Hipotesis keempat menyatakan bahwa persepsi konsumen secara tidak langsung berpengaruh signifikan terhadap minat beli melalui kualitas layanan. Berdasarkan hasil perhitungan secara tidak langsung, yaitu perkalian antara nilai $\mathrm{B}$ variabel persepsi konsumen terhadap variabel minat beli, sebesar 0,331. Sedangkan pengaruh langsung diperoleh sebesar 0,458. Ini berarti bahwa nilai pengaruh tidak langsung adalah lebih kecil dibandingkan dengan nilai pengaruh langsung. Hasil ini menunjukkan bahwa secara tidak langsung, persepsi konsumen melalui kualitas layanan memiliki pengaruh yang tidak signifikan terhadap minat beli pada ritel tradisional dan modern di Kota Langsa, maka hipotesis ditolak.

Hasil penelitian ini bertentangan dengan penelitian Siringoringo dkk. (2009) yang menyatakan pentingnya manajemen ritel memperhatikan pembentukan persepsi pada toko ritel jika ingin membentuk pengalaman berbelanja yang bagus dalam keputusan pembelian sehari-hari.

\section{e. Pengaruh Persepsi Konsumen Terhadap Kualitas Layanan dan Minat Beli pada Ritel Tradisional dan Modern di Kota Langsa}

Dalam bagian ini, pengaruh dibedakan menjadi pengaruh langsung, pengaruh tidak langsung, serta pengaruh total. Uraian analisis untuk setiap pengaruh itu sebagai berikut.

\section{(1) Pengaruh Langsung (Direct Effect)}

Berdasarkan hasil perhitungan menunjukkan bahwa persepsi konsumen memang memberikan pengaruh terbesar pada kualitas layanan. Begitu juga pada minat beli, persepsi konsumen juga memberikan pengaruh terbesar pada minat beli. Selanjutnya, kualitas layanan berpengaruh terhadap minat beli pada ritel tradisional dan modern di Kota Langsa.

\section{(2) Pengaruh Tidak Langsung (Indirect Effect)}

Berdasarkan hasil perhitungan menunjukkan bahwa terdapat pengaruh tidak langsung persepsi konsumen terhadap minat beli melalui kualitas layanan pada ritel tradisional dan modern di Kota Langsa. Pengaruh tidak langsung persepsi konsumen terhadap minat beli melalui mediasi kualitas layanan yaitu sebesar 0,331. Akan tetapi, hasil perkalian koefisien variabel persepsi secara tidak langsung lebih kecil dibandingkan nilai koefisien pengaruh langsung $(0,331>$ 0,458). Hal ini berarti bahwa persepsi konsumen lebih cenderung berpengaruh secara langsung terhadap minat beli pada ritel tradisional dan modern di Kota Langsa.

\section{(3) Pengaruh Total (Total Effect)}

Berdasarkan hasil perhitungan menunjukkan bahwa besarnya pengaruh total yang diberikan oleh variabel persepsi konsumen terhadap minat beli melalui kualitas layanan sebesar 1,206. Ini berarti bahwa persepsi konsumen merupakan faktor dominan dalam menentukan minat beli pada ritel tradisional dan modern di Kota Langsa.

\section{KESIMPULAN}

Berdasarkan hasil penelitian dan pembahasan, maka kesimpulan yang dapat disampaikan adalah sebagai berikut. Pertama, persepsi konsumen secara langsung berpengaruh signifikan terhadap kualitas layanan pada ritel tradisional dan modern di Kota Langsa. Kedua, persepsi konsumen secara langsung berpengaruh signifikan terhadap minat beli pada ritel tradisional dan modern di Kota Langsa. Ketiga, kualitas layanan secara langsung berpengaruh signifikan terhadap minat beli pada ritel tradisional dan modern di Kota Langsa. Keempat, persepsi konsumen secara tidak langsung berpengaruh tidak signifikan terhadap minat beli melalui kualitas layanan pada ritel tradisional dan modern di Kota Langsa.

Berdasarkan sejumlah kesimpulan itu, beberapa saran dapat disampaikan dalam penelitian ini. Pertama, perlu adanya peningkatan kualitas pelayanan baik di ritel tradisional maupun ritel modern sehingga dapat menumbuhkan minat beli konsumen. 
Kedua, perlu adanya peran serta pemerintah maupun pihak swasta sebagai salah satu sarana bagi pengusaha ritel dalam meningkatkan kapabilitas diri dalam bersaing di pasar sasarannya.

\section{DAFTAR PUSTAKA}

Amir, M.T. 2004. Manajemen Ritel. Jakarta: Penerbit PPM.

Dabholkar, P., Dayle, T. dan Rentz, J. 1996. A Measure of Service Quality for Retail Store: Scale Developmentand Validation. Journal of the Academy of Marketing Science. Vol. 24, Winter, hal. 3-16.

Ghozali, I. 2012. Aplikasi Analisis Multivariate dengan Program SPSS. Semarang: Badan Penerbit Universitas Diponegoro.

Hasan, A. 2013. Marketing \& Kasus-Kasus Pilihan. Yogyakarta: CAPS.

Hurlock, E.B. 1994. Psikologi Perkembangan: Suatu Pendekatan Sepanjang Rentang Kehidupan. Jakarta. Erlangga.

Lembaga Penelitian SMERU. 2010. Dampak Supermarket terhadap Pasar dan Pedagang Ritel Tradisional di Daerah Perkotaan diIndonesia. Jakarta.

Peraturan Presiden RI No. 112. 2007 tentang Penataan dan Pembinaan Pasar Tradisional, Pusat Perbelanjaan dan Toko Modern. Jakarta.

Remiasa dan Lukman. 2007. Analisis Persepsi Pelanggan terhadap Kualitas Layanan Coffee Shop Asing dan Coffee Shop Lokal. Jurnal Manajemen Perhotelan. Vol. 3, No. 2.

Riduwan. 2005. Belajar Mudah Penelitian untuk Guru, Karyawan dan Peneliti Pemula. Bandung: Alfabeta.
Sarwono, J. 2007. Analisis Jalur untuk Riset Bisnis dengan SPSS. Yogyakarta: Andi.

Schiffman dan Kanuk. 2008. Perilaku Konsumen. Jakarta: Indeks.

Setyawan, A.A. dan Ihwan, S. 2004. Pengaruh Service Quality Perception terhadap Purchase Intention: Studi Empirik pada Konsumen Supermarket. Usahawan. No. 7, Th. XXXVI, Juli, hal. 29-37.

Siringoringo, H., Swastha, B.D. dan Sugiharto, T. 2009. Model Pengaruh Persepsi akan Toko Ritel Modern pada Pengalaman Berbelanja. E-Journal Gunadarma. Vol. 1, No. 1, hal. 1-11.

Tambunan, T.T.H., Nirmalawati, D. dan Silondae, A. 2004. Kajian Persaingan dalam Industri Retail. Jakarta: Komisi Pengawasan Persaingan Usaha (KPPU).

Taylor dan Baker. 1994. As Assessment of the Relationship between Service Quality and Customer Satisfaction in the Information of Customer's Purchase Intentions. Journal of Retailing. Vol. 70, No. 2, hal. 163-178.

Tjiptono, F. dan Anastasia, D. 2000. Total Quality Management. Yogyakarta: Andi Offset. . 2004. Strategi Pemasaran. Edisi Kedua. Yogyakarta: Andi. dan Chandra, G. 2005. Service Quality Satisfaction. Yogyakarta: Andi.

Utami, C.W. 2006. Relationship Effort dan Kualitas Layanan sebagai Strategi Penguat Relationship Outcomes. Jurnal Manajemen Pemasaran. Vol. 1. No. 1, hal. 22-34. 